\title{
TEACHING ARABIC BY GENDER PERSPECTIVE AT PESANTREN DARUNNAJAH
}

\author{
Akmaliyah \\ Universitas Islam Negeri (UIN) Sunan Gunung Djati Bandung \\ Jl. A. H. Nasution No. 105 Cibiru, Bandung, Jawa Barat, Indonesia 40614 \\ Email: akmaliyah@uinsgd.ac.id

\section{Teti Ratnasih} \\ Universitas Islam Negeri (UIN) Sunan Gunung Djati Bandung \\ Jl. A. H. Nasution No. 105 Cibiru, Bandung, Jawa Barat, Indonesia 40614 \\ Email: tetiratnasih@yahoo.com
}

Received; December 2016; accepted June 2017; published June 2017

\begin{abstract}
This study was aimed at describing Arabic language teaching which is based on gender perspective at Pesantren Darunnajah Jakarta. Method applied to describe data was inferential descriptive. This method was used to describe, and organize systematically Arabic language teaching at Darunnajah then it drew conclusion based on the data gathered. The findings showed that Arabic language textbook had no material indicating gender bias. The involvement of male and female student in Arabic language material had no bias gender issues. However there was a little content or gender bias when dealing with activities and role of women either visually or textually. Textbook written by D. Hidayat featured: content on text concerning Muhammad SAW history, Siti Khadijah role and Indonesian women activities in the country.
\end{abstract}

Keywords: Arabic language teaching, Pesantren, Gender values

\begin{abstract}
ABSTRAK
Penelitian ini bertujuan untuk. memaparkan pengajaran Bahasa Arab perspektif jender di Pesantren Darunnajah Jakarta. Metode yang digunakan untuk mendeskripkan data yaitu metode deskriptif inferensial, yakni metode yang digunakan untuk mendiskripisikan, mensistematisir, pengajaran bahasa Arab di pesantren tersebut, kemudian mengambil kesimpulan umum dari bahan-bahan tentang obyek permasalahan. Dari hasil penelitian disimpulkan bahwa pada buku ajar yang disajikan tersebut tidak ditemukan nilai-nilai materi yang bias jender. Keterlibatan perempuan dan laki-laki atau santriwan dan santriwati pada contoh materi pengajaran babasa Arab itu tidak bias jender. Tetapi hanya sedikit materi yang mengungkapkan kegiatan dan peran perempuan baik secara visual maupun teks. Hanya pada buku karya D. Hidayat, terdapat contoh teks yang memuat sejarah Nabi dan menyebutkan peran Siti Khadijah dan beberapa gambar kegiatan perempuan di Indonesia.
\end{abstract}

Keywords: Pembelajaran Bahasa Aab, Nilai-nilai Jender, Pesantren.

\section{INTRODUCTION}

Arabic is the language of Qur'an, the language of Muslims' holy book. Or in the other words, Qur'an is revealed in Arabic. Arabic is also a religion language and a worship language of Muslim individually and socially. Thus, studying Arabic is a necessity for the perfection of Muslims' worship.

With the mastery of Arabic, Muslims are expected to read Qur'an well, understand its meaning and deepen the content of its' lesson to be practiced in daily life. With good Arabic 
skills, Muslims are expected to perform their daily worship perfectly. Finally, with this Arabic ability, Muslims can gain valuable benefits for the provision of life in the hereafter (ukhrawi value).

Attempts to achieve the Arabic skills are obtained through the process of teaching or learning, because learning is an attempt to gain a skill or knowledge (Poerwadarminta, 1986, p. 108). In the learning process consists of components of study namely participants, teachers, learning materials, teaching process, and evaluation. The word teaching originally comes from the word teach. In Kamus Besar Bahasa Indonesia (KBBI) (Setiawan, 2016), teaching is the process, the way, the act of teaching or teaching.

However, the awareness of gender perspective in teaching and learning atmosphere is still not fully applied especially in teaching Arabic. Some institutions and schools are still ignoring the value of gender perspective in teaching Arabic. Therefore, the teaching Arabic by gender perspective is urgently needed.

Associated with gender values in teaching Arabic, it also can be analyzed based on activities on the teaching component. In terms of outcomes, gender-based teaching can be said to succeed if it meets the following indicators: first, change of Arabic and gender knowledge mastery and also learners' attitudes and behavior in an integrated way; Second, learning outcomes obtained by learners through the process of teaching Arabic gender-based language has a usefulness and can be applied in daily life; Third, the learning outcomes can be remembered by learners and settle in their mind and it is enough to influence their behavior in gender values mastery in a long time, so that it will form a gender sensitive student's personality. Moreover, it can also give clear direction to solve their problems related to the values of gender equality.

Given the importance of Arabic as outlined above, the Indonesian government establishes the language curriculum at formal educational institutions. Starting from PAUD (early childhood education) up to university level. However, related to the extent to which the content of gender values equality in teaching Arabic is certainly still worth reviewing.

Based on the description above, it is necessary to conduct research on Gender Analysis in Teaching Arabic. Therefore, this study is set focus on teaching Arabic by gender perspective in Pesantren Darussalam Ciamis and Pesantren Darunnajah Jakarta.

The determination of research focus on Tsanwiyah (junior high school) and Aliyah (senior high school) students, because students at this level are assumed to have obtained sufficient knowledge and have received quite long time study period, since they entered the institution of elementary school until Aliyah. While the determination of Pesantren Darussalam Ciamis and Pesantren Darunnajah Jakarta as an analysis material of teaching Arabic by gender perspective, it is based on the assumption that the teaching Arabic in the two schools are sufficient and counted among Arabic academics.

\section{METHOD}

This study occupies a comparative case study. Kaarbo and Beasley (1999, p. 372) define a 'comparative case study' is the systematic comparison of two or more data points ("cases") obtained through use of the case study method,'. Kaarbo and Beasley (1999) also examine comparative case studies on the individual level (as opposed to the aggregate level where one nation is viewed as one case). This research is describe the teaching Arabic in Pesantren Darunnajah Jakarta. The decision to choose Darunnajah Jakarta to be analyzed based on the assumption that adequate teaching Arabic has been implemented there as well as the implementation of Islamic values in the curriculum of the institutions. Therefore, the gender values can be automatically concerned and cared. Moreover, it can be integrated in teaching Arabic at that institutions. 


\section{RESULT AND DISSCUSSION \\ Gender and Teaching Arabic at Pesantren}

\section{Gender concept}

The word gender in English can be pronounced by \'jen-der $\backslash$. The use of the term "gender" in the Bahasa Indonesia follows the sound or pronunciation of the original language of being jender.

In terminology perspective, gender is a cultural concept that seeks to make distinctions in the problems of roles, behaviors, mentality and emotional characteristics between men and women who are recognized by society. Furthermore, Hillary M. Lips defines that gender is the cultural expectations of men and women (Lips, 2005). Lindsey also stated all public determination regarding the determination of being male or female is included in the field of gender studies (Lindsey, 2015).

Gender is an analysis used in placing equal positions between men and women to bring a more egalitarian social order. The concept of gender equality is the balance or parallel between men and women as human beings who are not fully measurable rigidly and absolutely equal. Because between men and women have biological differences that can not be completely eliminated. From the biological differences will create the different behavior and duties or roles between men and women.

The differentiation of the roles, functions and responsibilities of men and women in this social context is essentially unproblematic, but when examined more deeply it can be the cause of gender discrimination, for example one gender neglected basic rights, lagging behind and experiencing injustice problems (Mufidah, 2003, pp. 7-8).

Various forms of gender gaps that occur in various areas of community life are also present in the education world. Even educational processes and institutions are seen to play a major role in socializing and conserving values and perspective underlying the emergence of various gender imbalances in society. Whereas, the 1945 Constitution Article 31 Paragraph 1 states that "Every citizen have the right to receive education". The article implies that both men and women have equal rights in tasting education, but in reality there is still discrimination for both men and women in two respects; First, labeling (stereotype), labeling of male or female gender with positive or negative connotations; And second, subordination, subordination treatment that causes a person to occupy a lower position than others, so it does not get priority (Djunaedi \& Muzayyanah, 2008, p. 17).

\section{Teaching Arabic at pesantren}

Teaching Arabic in pesantren is a compulsory subject of both salafiyah (traditional pesantren) and khalafiyah (modern pesantren). It is because the mastery of Arabic is the main capital for studying other books material in pesantren.

Some teaching methods in pesantren, including teaching Arabic, are:

a. The traditional methods

1) Wetonan, a method of following the lesson by sitting around the kiai (teacher) who are explaining the lesson. The students gave their attention to their books and then writing down if necessary.

2) Sorogan, a method of learning by facing the kiai one by one while carrying the material book that will be studied.

3) Memorization, a method of learning in memorizing certain text or sentence from the book they studied.

4) Mubawarah, a practice conversation with arabic that is performed by santri (students) during their stay in boarding school. This learning activity is done in khalafiyah in general by requiring the use of this method every day. 
b. Combined methods

As the times progressed, pesantren began to consider and take over the national education methodology and some pesantren adapted to the educational system in formal educational institutions, while some still retained the old teaching methods. Even though there are still pesantren that only apply the traditional methods, but pesantren that combine various methods with non-classical system in the form of madrasah, is still done. Finally, the situation in the teaching and learning process varies and causes the students to become more enthusiastic and motivated in learning because of the application of various methods performed in a combinative way, between traditional and modern.

Arabic language in Madrasahs has characteristics as a language subject directed to encourage, guide, develop, and nurture abilities and foster positive attitudes towards Arabic, both receptive and productive. Receptive ability is the ability to understand other people's conversations and understand reading. Productive ability is the ability to use language as a means of communication both orally and written.

Arabic skills as well as positive attitudes towards Arabic are very important in helping to understand the source of Islamic teachings of the Qur'an and Al-Hadist, and Arabic books related to Islam for learners. Therefore, Arabic in Madrasah (Islamic School) is prepared for the achievement of basic language competence, which includes four integrally taught of language skills, namely listening (mahärat al-istima $\bar{a}$ ), speaking (mahärat al-kalām), reading (mahärat al-qiräáa) and writing (mahärat al-kitäbah).

The Arabic in pesantren is used as the medium of instruction to understand the teachings of Islam. Thus teaching Arabic is integrated in the teaching of Islamic Religious Education which is understood in depth from its main sources, namely Al-Qur'an and AlHadist as well as Arabic-speaking supporting literatures such as Tafsir and Hadith.

Arabic course is a subject that is directed to encourage, guide, develop, and nurture ability and foster positive attitude towards Arabic both receptive and productive. Receptive ability is the ability to understand other people's conversations and understand reading. Productive ability is the ability to use language as a means of communication both orally and in writing. Arabic language skills as well as positive attitudes towards Arabic are very important in helping understand the source of Islamic teachings of the Qur'an and Al-Hadith, as well as Arabic books related to Islam for learners.

Through learning Arabic can develop students' skills in oral and written communications to understand and convey information, thoughts, and feelings. Thus, Arabic subjects are needed for the students' self-development so they can grow and develop into smart and skillful citizens who are able to develop science, technology, and culture and be ready to take part in national development.

Teaching Arabic as a tool or medium to achieve educational goals in accordance with the function of the curriculum. When starting from the definition of curriculum work, it can be understood that the school curriculum is basically as a tool to achieve the educational goals to be achieved. One possible action is to review the objectives that a school is currently using to motivate learners to think positively about learning Arabic. The learners are reminded again of the curriculum objectives and the purpose of learning Arabic in madrasah, that is learning to use the language as a communication tool, both oral and written, not to know qawa'id or grammar itself deeply.

The curriculum is an integral part of education or teaching. The curriculum has a central position in an educational process. The curriculum directs all forms of educational activities for the achievement of educational goals. The curriculum is also an educational plan, providing guidance and guidance on the type, scope and sequence of content and educational 
processes. Arabic is taught as one of the important subjects in Madrasah Aliyah in the structure of Islamic studies curriculum.

The Arabic curriculum is the whole situation, language experience, and communicative activities that are offered, prepared, selected, planned, and arranged so that language learners have the ability to develop and practice the language either listening, speaking, reading or writing (Tha'imah \& al-Naqah, 2006, p. 90).

According to Tha'imah (2006, pp. 125-131) the Arabic curriculum consists of several components, as follows:

a) Goal

The Arabic curriculum has two purposes, namely general goals and specific goals. The general purpose of the Arabic curriculum is to understand Arabic fluently and correctly, and to listen to it in an oral context, Arabic dialogue by communicating directly, reading Arabic and understanding its meaning, writing Arabic correctly. While the specific purpose is the translation of each language proficiency.

b) Curriculum content

The contents of the Arabic learning curriculum consist of three elements, namely linguistics, culture, and communication. These three elements will be formed as abilities that must be mastered by students. The standardization of the Arabic curriculum for non-Arabs is based on the opinions or theories of experts especially in Arabic learning, the linguistic theories and psychological theories, analyzing the needs of their language learners, interests, and desires, adapting to the goals and skills that will be accomplished.

c) Method and media

Method is one of important element in curriculum. Once there is a goal, what curriculum content, and what level of students will be taught and already know the character of the students and the differences of each learner or the abilities they have, then we can limit and choose what methods and strategies are appropriate. In addition, once the method is selected there are important things that will be done to support the learning of the media because the use of media in the implementation of methods or strategies. For now, many media options can be used in Arabic learning such as many technologies media.

d) Evaluation

Evaluation is very important to be done to determine whether or not the learning process is done, whether or not it is achieved. Therefore, evaluation is not only given to the students, but the evaluation of the whole components of the curriculum, whether objectives, curriculum content, methods and media, as well as evaluations carried out.

The Arabic curriculum in Indonesia is widely used, the latter is the Education Unit Level Curriculum (KTSP), which is an operational curriculum developed by and implemented in each educational unit (school or madrasah).

Apart from the explanation above, specifically the Arabic subjects in pesantren have positions as compulsory subjects and scope of religious subjects sciences with the following objectives:

a) Developing the ability to communicate in Arabic, both oral and written, which includes four language skills, namely listening (istima $\vec{a}^{-}$, speaking (kaläm), reading

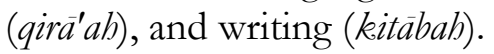

b) Growing awareness of the importance of Arabic as a foreign language to become the main tool of learning, especially in studying the sources of Islamic teachings.

c) Develop an understanding of the interconnectedness between language and culture and broaden the cultural horizon. Thus, learners are expected to have cross-cultural insights and involve themselves in cultural diversity. 


\section{Teaching Arabic at Pesantren Darunnajah Jakarta}

Pesantren Darunnajah is a privat Islamic education institution that has been built since 1942. KH. Abdul Manaf Mukhayyar and his two colleagues, KH. Qomaruzzaman and KH. Mahrus Amin, are the founders who built with an integrated curriculum system, boarding education and intensive English and Arabic teaching.

Pesantren Darunnajah is located at Jalan Ulujami Raya, number 86, Ulujami, Pesanggrahan, South Jakarta, DKI Jakarta Province. The location of the pesantren is very profitable because it is on the outskirts of the capital, which makes it easier for communication, both with government agencies and with the wider community. Supported by a beautiful environment, Darunnajah Islamic Boarding School attempts to print middafaqih fiddin human to become agent of nation leaders, always strives to create educated santri who has sincere spirit, simplicity, independence, ukhuwah Islamiyah, freedom of thought and behavior on the basis of Al- Quran and Sunnah Rasulullah SAW to increase taqwa to Allah SWT.

As a kind of modern pesantren, santri of Pesantren Darunnajah are open minded and moderate, without eliminating element of Islam. Discipline and simplicity are applied in everyday life in the campus environment. This is due to the fact that the management of education and teaching as well as daily santri activities are carried out by teachers or religious teachers with educational background from various universities and modern pesantren who mostly live in dormitories and fully supervise and guide students in the process of activities Learning to teach and control the santri.

The vision of Pesantren Darunnajah is, "Printing a muttafaqah fiddin people to become a leadership cadre of nation". Moreover, the mission is to "Educate the cadres of the people and nations with tafaqqah fiddin; The scholars, zuama and aghniya, pious Muslim scholars, noble, knowledgeable, healthy, skilled and tenacious bodies. On that basis, in the effort to achieve the vision and mission, the Pesantren Darunnajah apply archetype in education which include:

1) Panca Jiwa, namely education implemented to each santri to shape and underlie her/his personality; (A) the sincerity soul; (B) the simplicity soul; (C) an independent soul; (D) the ukbuwah Islamiyah soul; And (E) an independent and free spirit.

2) Panca Bina, namely the direction of santri coaching that will create a real attitude of life in the steps and daily amaliah, which includes; (A) piety to Allah SWT; (B) having a noble character; (C) Healthy bodies; (D) broad-minded; And (E) creative and skillful.

3) Panca Dharma, namely The devotion of santri as creatures, members of society and citizens, so that the existence of santri is not only beneficial to themselves, but also beneficial to others and the natural surroundings, embodied in terms of; (A) worship; (B) useful knowledge in society; (C) cadre of ummab; (D) da'wah Islamiyab; And (E) the love of the homeland and the insight of the archipelago.

Pesantren Darunnajah embraces a collective leadership system, in which the highest leadership is held by three people at once with the job division in accordance with the expertise of each personal. In terms of education system, Pesantren Darunnajah apply three education system; Modern pesantren system, madrasah system, and salaf pesantren system.

Teaching in Pesantrren Darunnajah involves women and men, classically and separately. In an effort to achieve education, Pesantren Darunnajah is a boarding school of pesantren modern either for man or woman ranging from the level of Play Group, PAUD, kindergarten, elementary, MTs (Tsanawiyah), MA (Aliyah), SMA to Higher Education. Darunnajah. As for the santri activities, among others: Praying in congregation 5 times, studying the Qur'an, memorizing Al-Qur'an (tahfidz), Arabic and English conversations, organizational exercises, 
speech exercises, sports, scouts, and extracurricular activities such as silat, Journalism, marching band, and so forth.

Teaching in Pesantrren Darunnajah involves women and men, classically and separately. In an effort to achieve education, Pesantren Darunnajah is a boarding school of Modern Pesantren for santri either woman and man ranging from the level of Play Group, PAUD, kindergarten, elementary, MTs (Tsanawiyah), MA (Aliyah) to Higher Education. Darunnajah as for santri activities, among others: 5 times praying in congregation, studying the Qur'an, memorizing Al-Qur'an (tahfidz), Arabic and English conversations, organizational exercises, speech exercises, sports, scouts, and extracurricular activities such as silat, Journalism, marching band, and so forth.

Pesantren Darunnajah prefers education rather than teaching, because education is not only sharpens the mindset of santri, but rather to the formation of santri's personality in all of their life. Therefore, the meaning of education in Pesantren Darunnajah is more directed to: (a) education cadres of the people who are able and skillful in the middle of society, related to Arabic language education that is expected to be useful in the future society; (B) Guidance of the young generation who are able to continue their studies in accordance with their talent and moreover remain in the community by upholding amar ma'ruf nabi munkar. To continue their studies in college the students are required to master a foreign language, including the Arabic Discuss.

From the beginning of the year until 2014, Darunnajah entered the age of 40. Pesantren Darunnajah has graduated 37 batches, with a total of approximately 17,000 santri. The development of students from the first santri (1974) until 2014 is very significant. Initially, the amount of santri are 3 (three) people, then the number of santri Darunnajah has increased up to 15. In March 2014, there were 8,970 santri. Until 2016, the time of this research done, the number of santri are 2360 people. The development number of students is certainly followed by the development of management: education system, parenting system, administration and finance system, maintenance system and public relation system.

Associated with Arabic, which since the founding of Pesantren Darunnajah has been proclaimed as the official language in Darunnajah, in addition to English and has undergone changes ranging from teaching methods and language learning, the use of textbooks, to the ups and downs of the quality of Arabic at santri. This is due to many factors, both from the development number of santri, disciplinary rules, stakeholder responses, and other factors that influence the development of language.

Nevertheless, many things have been done and are being done by Pesantren Darunnajah in an effort to continue to make and position the Arabic as Taajul Ma'bad (the crown of Pesantren). The efforts that have been implemented by Pesantren Darunnajah in an effort to maximize the use of Arabic, including: Hospitality Field or commonly called the Bureau of Hospitality. It is one of the Bureau in Pesantren Darunnajah that oversees all the affairs of students outside the classroom, including in the department of language that is run by the senior santri. The Language Section in the Organization of Santri Darunnajah, is given a full mandate for language development by undertaking various Arabic and English development activities.

The next effort is in the field of education, commonly called the Bureau of Education, oversees 54 educational levels, all levels of education from playgroup, kindergarten, elementary, Tsanawiyah, and Aliyah in Darunnajah and branch. Among the efforts undertaken in the framework of Arabic development is the provision of Arabic subjects since the kindergarten to upper secondary level. Nevertheless, intensive Arabic learning is conducted at the level of Tarbiyat al-Mu'allimin-at al-Islamiyah (TMI) which is equivalent to SLTP - SLTA. 
The intensive and specific programs of formal teaching Arabic are as follows:

a) Teaching Arabic at all levels

b) Arabic as the language of instruction in religious or general subject

c) Implement the activities of Amaliyah Tadris (teaching practice) by using Arabic and English introduction

d) Using Arabic and English laboratories as a means of multimedia in language learning

e) Require all students to perform the activities of writing al-Insya al-Yaumi in Arabic and daily conversation in English and corrected by musyrif

f) Teaching some of the yellow books (religious material books) as a medium to understand the poles of turats and means of understanding Arabic texts

g) Bringing native speakers to support foreign language learning.

Relating to native speakers and cooperation that has been done by Pesantren Darunnajah in order to present native speakers, among others:

a) Cooperation with Al-Azhar University Cairo Egypt, since 1991-present

b) Cooperation with Universitas Islam Madinah (UIM) in al-Daurah al-Tadribiyyah fi alLughah al-Arabiyyah wa al-Tsaqäfah al-Islämiyah wa al-Muqäbalah since 2009-present

c) Cooperation with Holy Family Schol (HFCS), one of secondary school in Keighley, West Yorkshire, England. Since 2006-present, students and teachers exchange.

d) Following other activities in improving foreign languages.

e) Following Youth Exchange and Studies Programme in USA, has sent 13 students.

f) Following Young Ambassador Program of Ministry of Foreign Affair to Australia, Japan, Thailand, Vietnam and Philipine

g) Following World Jamboree in various countries such as Thailand, Australia, South Korea, Japan, Arab, Egypt, Holand and Brunei

h) Language Improvement for teachers, in some overseas institutions, including: AlAzhar University Cairo Egypt, Arab Academy Cairo Egypt, Ummul Qurra University, Makkah, Saudi Arabia, and Hallab University, Alleppo, Syria.

i) Darmasiswa Program for foreign students funded entirely by the Ministry of Education and Culture, Republic of Indonesia since 2011; Senegal, Czech Slovakia and Myanmar.

Similarly, several things done by Pesantren Darunnajah in the effort of developing and improving Arabic. Teaching Arabic is using the book of Al-Lughah al-Arabiyyah by H. Nur Hamid, M.pd, the publication of pesantren darunnajah, and the book of Ta'limu al-Lughah alArabiyyah by D. Hidayat, published by Toha Putra Semarang, based on curriculum of Ministry of Religious Affair decision. As well as a book of Durûs al-Lughah al-Arabiyyah by Imam Zarkasy and Imam Syibani.

\section{Gender Analysis in Teaching Arabic at Pesantren Darunnajah}

To analyze gender in the teaching Arabic at Pesantren Darunnajah, the researcher attempts to address the phenomenon of gender gap in education that has been described in previous dissemination:

1) Under Participation

In terms of educational participation, male students in Pesantren are facing problems of teaching compared to the opposite sex. Their participation in teaching seems lower because in this case female students have greater motivation and achievement than male students.

2) Under Representation

As a result of the lack of participation of male students in the teaching of Arabic, the representation of male students shows a decline. 


\section{3) Unfair Treatment}

Learning activities and interaction processes in classroom is running balanced. The teacher gives equal treatment and care to both male and female students. They assume that men and women should have equal opportunity in terms of having an opportunity in teaching Arabic.

The dimensions of access in the pesantren are said to be evenly distributed between the number of male and female students. In addition, the form of rubric material and illustration drawings in some textbooks are based on macro aspects consisting of indicators, subordination, marginalization, stereotypes, hardness and double burden as the micro scope of access, participation, and control that has a tendency to the emergence of subordination, marginalization and accompanied by the existence of negative labeling to the women, causing the restriction on women's access and participation especially in the sphere of public affairs.

It can be seen from the learning materials contained in Arabic textbooks, namely:

a) Cover of Arabic book consists of pictures of male students and female students

b) Arabic material has not balanced the theme of the subject between the study of men and women

c) There is a theme of "al-Mibnab" which means asking for the position of women only described as housewives. While the formal position in the book is occupied by men. So there is a gender bias. That is favoring one of the sexes in social life or public policy. Gender bias in education is the educational reality that favors a particular gender causing gender inequality.

According to Asrohah (2008, p. 178), efforts to overcome gender bias in teaching Arabic can be done as follows:

a) The content of national curriculum should not perpetuate the dichotomy between men and women, as well as local curricula based on equity, justice and equilibrium. The curriculum is structured according to the needs and typology of the area starting from the education level of Kindergarten or early childhood up to the level of Higher Education.

b) Schools review and improve the provision of gender-sensitive textbooks at all levels of education, including text, images and equal access to learning activities.

c) The teacher formulates a learning strategy that regulates the placement of qualified male and female students in all learning activities.

d) A model of gender understanding in Islam that is able to accommodate traditional gender concepts that are deeply rooted in the minds of educators and learners. Especially, in this case the educator so as not to feel strange and feel confronted with teachings that are completely new and as if un-Islamic. The need for a reinterpretation of the gender discourse socialization model by integrating the principles of justice and gender equality with the principles of Islamic Education that can accommodate the demands of gender equality.

In fulfilling equality and gender justice stated above, education needs to fulfill the basic of education that is delivering every individual or people to get education. Therefore, it can be called populist education. In the end, justice and equality are the basic ideas, goals and mission of human civilization to achieve welfare, build harmony of social life, state and build a quality family. Gender equality is the equality of conditions for men and women to obtain opportunities and rights as human beings, in order to be able to participate in political, legal, economic, socio-cultural, educational and defense and national security activities and equality in enjoying development results. Gender equality is a fair treatment of women and men. Biological differences can not be used as grounds for discrimination concerning social, cultural, legal and political rights to a particular sex. Gender equity means that there is no 
standardization, double burden, subordination, marginalization and violence against women and men. The realization of gender equality and justice, characterized by the absence of discrimination between women and men and thus they have access, opportunity to participate and control over development and obtain equitable and fair benefits from

The gender understanding and orientation of santris and teachers of pesantren in Indonesia are still mixed up with fate, so that social problems in the society are always justified by textual rules in religion (Astuti, 2012). In the term of teaching Arabic in gender perspective in Indonesia, the government needs to take a role to control the contain of teaching and learning in all education institution especially the content relating to the gender. This contribution will minimize the gender perspective problems that seems significantly arouse in Indonesia's education life.

\section{CONCLUSION}

Teaching Arabic in gender perspective at Pesantren Darunnajah Jakarta as a whole reflects gender responsiveness. Teachers consisted of men and women, as well as the santri consisting of santriwan (male students) and santriwati (female students) who received the same teaching, materials and evaluation. Teaching materials also contain gender responsive values.

Nevertheless, some of the inhibiting factors of teaching Arabic gender perspectives are still a non-uniform understanding of gender values so there is still gender biased material. This is because Arabic is a patriarchal Arabic cultural product. In some books it seldom exemplifies the activities of women, including the picture of their activities.

\section{BIBLIOGRAPHY}

Asrohah, H. (2008). Sosiologi pendidikan. Surabaya: Kopertais Press.

Astuti, T. M. P. (2012). Gender construction in pesantren in Johor (Malaysia) and Central Java (Indonesia). Humaniora, 22(2), 125-141.

B.Miles, M., Huberman, A. M., \& Saldana, J. (1999). Qualitative data analysis. London: SAGE Publications Ltd. Retrived from http://www.theculturelab.umd. edu/ uploads/1/4/2/2/14225661/ miles-huberman-saldana- designing-matrix-andnetwork-displays.pdf

Bricki, N., \& Green, J. (2007). A guide to using qualitative research methodology. Retrived from http://fieldresearch.msf.org /msf/bitstream /10144 /84230/1 / Qualitative+research+methodology.pdf

Denzin, N. K., \& Lincoln, Y. S. (2009). Handbook of qualitative research. Yogyakarta: Pustaka Pelajar.

Djunaedi, W., \& Muzayyanah, I. (2008). Pendidikan Islam adil gender di madrasah. Jakarta: Pustaka STAINU.

Farquhar, J. D. (2012). Case study research for business. Sage. Retrived from https://books.google.com

Lindsey, L. L. (2015). Gender roles: a sociological perspective. Routledge.

Lips, H. M. (2005). Sex and gender. McGraw-Hill.

Mufidah, C. (2003). Paradigma gender. Malang: Bayumedia Publishing.

Poerwadarminta, W. J. . (1986). Kamus umum bahasa indonesia. Jakarta: Balai Pustaka.

Seidman, I. (2015). Interviewing as qualitative research: a guide for researchers in education and the social sciences, 4th ed. Teachers College Press.

Setiawan, E. (2016). Arti kata ajar - Kamus Besar Bahasa Indonesia (KBBI) online [Dictionary]. Retrived from http://kbbi.web.id/ajar

Tha'imah, R. A., \& al-Naqah, K. (2006). Ta'lim al-lughah ittisholiyyan baina al-manabij wa alistiratijiyyat. Rabath. 